\title{
CHEMISTRY
}

\section{HYDRO ISOLATION MATERIALS, LUMINOPHORE AND OTHER DEFICIENT PRODUCTS, INNOVATIVE TECHNOLOGY}

\author{
Guram Khitiri, $P h D$ \\ Ioseb Chikvaidze, PhD \\ Raul Kokilashvili, PhD \\ Tinatin Gabunia, $P h D$ \\ Madona Tsurtsumia, PhD
}

Georgia, Tbilisi, TSU, Petre Melikishvili Institute of Physical and Organic Chemistry, Laboratory of Petroleum Chemistry

DOI: https://doi.org/ 10.31435/rsglobal_ws/30122018/6268

\section{ARTICLE INFO}

Received: 10 October 2018

Accepted: 26 December 2018

Published: 30 December 2018

\section{KEYWORDS}

Luminophore, bitumens, waste, petroleum, isolation, paraffin.

\begin{abstract}
. One of the main objectives of the project is to develop a methodology for obtaining high quality water-proofing materials. The abovementioned high-melting tar mass will be used as the main raw material. Especial treatment and further homogenization of the mass - mixture of high-dispersive quartz sand, silicates and other wastes - gives possibility to make various universal and inexpensive compositions. With the aim to improve hydro-insulating and other specific characteristics of the compositions they will be varied by changing the ratio of ingredients. The elasticity of these compositions is conditioned by macromolecular paraffin-ceresin and the polymeric (rubber) components; varying the strength and adhesion is possible by soluble and insoluble silicate-quartz components. The mentioned components can be got in a large amount in region. Therefore, products obtained from cheap raw materials will be inexpensive. The use of the mentioned waste is also important to avoid the pollution of nature. Operating characteristics of the proposed luminophore satisfy requirements of international standarts. In particular, the solutions made from it have an ability to detect invisible cracks of the thick $<1 \mathrm{~mm}$. The light intensity in its greenish-yellow area is 4,5-5 times more than that of standard - uranyl nitrate. It is stable with high quantum efficiency $(40-45 \%)$.
\end{abstract}

Citation: Guram Khitiri, Ioseb Chikvaidze, Raul Kokilashvili, Tinatin Gabunia, Madona Tsurtsumia. (2018) Hydro Isolation Materials, Luminophore and Other Deficient Products, Innovative Technology. World Science. 12(40), Vol.1. doi: 10.31435/rsglobal_ws/30122018/6268

Copyright: (C) 2018 Guram Khitiri, Ioseb Chikvaidze, Raul Kokilashvili, Tinatin Gabunia, Madona Tsurtsumia. This is an open-access article distributed under the terms of the Creative Commons Attribution License (CC BY). The use, distribution or reproduction in other forums is permitted, provided the original author(s) or licensor are credited and that the original publication in this journal is cited, in accordance with accepted academic practice. No use, distribution or reproduction is permitted which does not comply with these terms.

Introduction. Water-proofing of concrete, ferroconcrete, metal, wood and other construction structures, pipelines of various purpose, including oil- and gas pipelines, as well as agglutination of metal-concrete, metal-wood and other combinations is one of the most important and actual problems. Materials of such types are not produced in Georgia. Import, transportation, customs duty of those products and other expenses significantly increase the value of structures. Thus, the use of these materials is unprofitable. Analogous situation is in the field of separation of paraffin and ceresin, 
petrolatum, luminophore and different types of bitumens from oil, on the basis of which it is possible to produce small-scale deficient inexpensive products [1].

The production of the above-mentioned materials from the local raw materials and various types of waste is highly relevant in Georgia.

To this end, the first step is to create laboratory and experimental modeling methods as a basis for the future production technologies.

The strategic goal of the project is to create zero-discharge treatment schemes for organic and mineral wastes to produce various types of deficient products in Georgia and, in addition, to avoid pollution of the environment [2].

The project proposal deals with the preparation of various compositions of hydroinsulation materials from inorganic components and oil waste in Georgia. It is also taken into account the separation of luminophore, paraffin-ceresin and bitumen masses of various types from the wastes in pipelines. The latter will be used as one of the components in waterproofing compositions.

\section{Materials and methods.}

All used chemicals were of analytical grade.

AFP Silica gel (activated fine porous silica gel) - manufacturer: Labstatus Ltd (Ukraine); Petroleum ether (Sigma-Aldroch International GmbH, Germany).

\section{Research results.}

The purpose of the project is to create the basis for the production of hydroinsulating materials and small-scale deficient, high-quality products - paraffin and ceresin, petrolatum, luminophore, lubricants and bitumens for various purposes.

The novelty is the use of sedimentary waste in the oil pipeline to produce small-scale deficient and expensive products such as: [3]

1. Paraffin $\left(\mathrm{C}_{25}-\mathrm{C}_{35}\right.$; melt temperature $50-65{ }^{\circ} \mathrm{C}$ and more $)$ and ceresin $\left(\mathrm{C}_{36}-\mathrm{C}_{53}\right.$; melt temperature is whithin the range $50-65^{\circ} \mathrm{C}$ ), which are of great demand for industrial and domestic purposes;

2. luminophoric component is needed to detect invisible cracks with the methods of luminescent marking and luminescence microscopy;

3. High-melting tar mass is needed to obtain raw insulation materials (water-proofing and anticorrosive ones), electrode coke and high-melting bitumen.

This is also important to avoid pollution of the environment [4].

Calculations showed that the use of waste is reasonable and economically profitable if the content of the oil components is more than 30\%. The Baku-Tbilisi-Ceyhan oil pipeline contains 60-75\% and more oil components. Therefore, separation of the above-mentioned products from the waste for the further use is prospective to produce cheap materials.

The project plan provides fractioning of sedimentary waste in the oil pipeline and clearing fractions without using traditional, expensive stages and adsorbents, catalysts and reagents. Specifically, melting of sediment and fractionation of viscous mass is provided by rectification (under atmospheric pressure) and molecular distillation $\left(1 \cdot 10^{-3} \mathrm{~mm} \mathrm{Hg}\right.$ column residual pressure) up to the temperature of $80-550^{\circ} \mathrm{C}$; obtaining the following five fractions as a result of the rectification:

1. Fraction $80-190^{\circ} \mathrm{C}$ - a) Solvent for industrial-technical purposes, b) Petroleum component;

2. Fraction $190-300{ }^{\circ} \mathrm{C}$ - Diesel fuel component;

3. Fraction $300-350{ }^{\circ} \mathrm{C}$ - Diesel fuel component with high cetane number;

4. Fraction $350-450{ }^{\circ} \mathrm{C}$ - Paraffin-ceresin component to produce candles, lubricating grease, petrolatum, ointments and creams, mastics, impregnants, etc;

5. Fraction $>450{ }^{\circ} \mathrm{C}$ - raw material to obtain electrode coke, water-proofing materials, bitumens and luminescence components, etc. [5];

6. Two more fractions: $450-500^{\circ} \mathrm{C}$ (for obtaining high quality luminophore) and $500-550{ }^{\circ} \mathrm{C}$ (for obtaining high quality electrode coke) will be got by distillation of remaining viscous mass.

Table 1. Parameters of residue and isolated tar oil

\begin{tabular}{|c|c|c|c|c|c|c|c|c|c|c|}
\hline 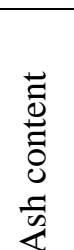 & 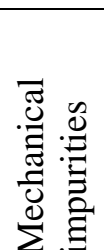 & 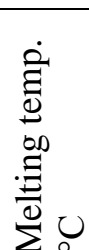 & $\begin{array}{l}00 \\
\frac{\tilde{y}}{0}\end{array}$ & 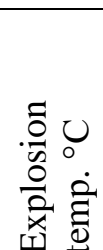 & 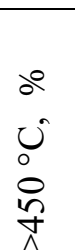 & 总 & $\begin{array}{l}\partial 0 \\
\dot{\theta} \\
\overline{0} \\
\dot{d}\end{array}$ & 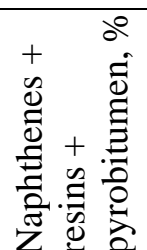 & 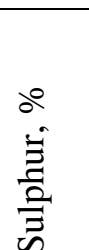 & 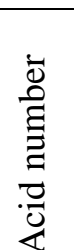 \\
\hline 26 & $83 .=$ & $\begin{array}{l}-10 \\
-10\end{array}$ & 35 & $62=$ & 250 & 35 & 26 & $\frac{2}{38}+2$ & 0.17 & 0.15 \\
\hline
\end{tabular}




\section{Conclusions.}

The 5th fraction $\left(>450^{\circ} \mathrm{C}\right)$, and the residue left after the molecular distillation are to be used as the main component for preparing the test waterproofing compositions. Then the highly dispersed secondary organic components (polimeric and/or rubber) and also highly dispersed inorganic components (sand, gravel), then soluble glass (silicate solution) and other special additives will be added. Finally, these mixtures will be homogenized at the temperature $60-75^{\circ} \mathrm{C}$ and intensive stirring.

Obtaining of different samples of test hydro-insulation compositions is planned by varying the component mass ratio and the type and quantity of specific additives. The study of mechanical and the physical and chemical parameters of each sample will allow us to select the optimal composition of the insulation material according to the specifics of its use.

The preparation of insulation materials for the following purposes is provided:

- Waterproofing of concrete, ferroconcrete, metal, wood and other construction structures; filling and bonding of cracks;

- Flat roofing;

- Isolation of pipelines, including oil- and gas pipelines (hydro- and anti-corrosive isolation).

\section{REFERENCES}

1. Guram Khitiri, Ioseb Chikvaidze, Tinatin Gabunia, Madona Tsurtsumia. Study and Wasteless utilization of the residue after profilaxis of oil pipe-line. Bulletin of Georgian National Academy of Sciences, vol.9, \# 3, 2015.

2. Tiagunova G. V., Iaroshenko Iu.G (2005) Ecology M. 504 p. (in Russian).

3. Guram Khitiri, Rusudan Akhibadze. Method of obtaining luminophor. Patent P4054, 2005 (in English).

4. Guram Khitiri, Ioseb Chikvaidze. Method for wasteless utilization of oil pipeline residues. Patent.GE P 20186831 B.

5. Sharifullin A. V., Baibekova L. R., Suleimanov A. T. Peculiarities of composition and structure of petroleum depositions. Technology of oil and gas. 2006, \# 6, pp. 19-24. 